\title{
Gauging the Access of Covid- 19 Global Pandemic, And Safeguarding the Dignity of The 1945 Values Toward The Powerful Indonesia
}

\author{
Made Yudana \\ made.yudana@undiksha.ac.id \\ Universitas Pendudukan Gnesha
}

\begin{abstract}
This academic study is intended to affect the conscience of every human being, especially for Indonesian, they should realize how important and urgent it is to carry out social resilience, by strengthening the 1945 values as the core values of life in our very diverse society. Fastening social relations is a necessity if we do not want to experience disintergration. Because in the end, disintergration only triggers the nationality erosion. We should avoid this nightmare together as a nation. Especially, in the midst of Covid-19 pandemic, people become more miserable because there is a downturn in almost all life sectors. This study was written using a critical social descriptive method. It measures the excesses of the Covid-19 pandemic, and to learn the traces of Indonesia's journey from time to time. Realizing that globalization and technology have the potential to be tonic and toxic. Therefore, we must be smarter in choosing and sorting them out. Finally, there are five solutions that offer solutions on how to strengthen our social solidarity as a nation, avoiding the nationalism erosion in the midst of a pandemic, because like the history of our country, we should not fall on the same pole twice. Hopefully.
\end{abstract}

Keywords: Towards Powerful Indonesia in the Midst of the Covid-19 Pandemic

\section{Introduction}

A history occurred time, although in a fragment of time that happened in the past. However, in living today's life and predicting the future it will be unwise if one forgets the past since the existing generation that live in three fragments of time have a very close relation with them, the current generation in planning their welfare will always refer to and learn from the past, and in their departure from the current condition they will at the same time plan a stronger future.

The paragraph above is expected to arouse our commitment as the children of the nation to make an introspection as to how far we need to reconstruct the concept of our nationalism to become more visionary, to be able to penetrate the hindrances in a number of factors , internal as well as external, and to be able to envisage the future in the time and spatial perspective. The fact shows that today we are living in a situation and a condition of geat concern, two years in the trap of Covid-19 pandemic that has devastated all the pillars of our life as a nation. If in the critical situation like this as a people of a nation we lack wisdom in responding various forms of social problems that are occurring,it is not impossible that in the downstream it can be predicted that the building of nationalism that we have strongly constructed in 1945 is being undermined. 
This is not an illusive prediction or a fantasy that is not backed up with any reason. Two years of pandemic has ruined the pillars of our economy as a nation, which has lowered down the level of poverty, has increased the rate of open unemployment and lowered down the welfare index, since many people are losing their jobs because of the laying off of workers in many companies and even various big industries are going bankrupt as if there were a monster in the daytime since there are a lot of people who are becoming jobless because of the industries where they used to work and which were the sources of their incomes are unexpectedly going bankrupt and they are forced to be layed off. The repercussion of this phenomenon is that even today most of our people are experiencing limitation and social problems even they have problems meeting their basic needs and they are now in the labyrinth of uncertainty.

The phenomenon of the susceptibility to illnesses and the fragility of health are caused by pandemic, which is closely related to socio-economic recession, can lead to the phenomenon of the degradation of nationalism which has been stated by many people is the result of two dimensions, that is, our poor understanding of the history of the nation on the one hand and our inability to predict our future on the other hand.

What is regrettable is that this phenomenon often recurs even when there is a small event of momentum in this country. The most recent example was when Joko Widodo's second term presidential election (PILPRES) took place in which Joko Widodo competed with Prabowo Subianto, how concerned were we since this nation was "almost" divided by the sinical jargons from both groups with the title " kecebong and kampret" (tadpole and small bat). We thanked God that this division did not last long like the previous traditions., since in both groups there were the cultures of wisdom, full of understanding and elegance, especially on the part of the winning party which did not continue this presidential election competition to a permanent rivality with the zero sum game.

Now in the pandemic time, when ideally all components of the nation unite, hand in hand in finding a solution to the pandemic, an anomaly of concern is arising once again. Now when people are shocked since they are vulnerable to meet the need for food as the most important basic need for survival, many people are manipulating this issue, using the situation for their benefits, like the criminal armed group in Papua, various attacks by bullying and anger in the social media, hoaxes that are misleading in the public space, and even a display of a mural of Joko Widodo's face in Batuceper Tangerang. That is not all. The Senayan group, our parliament member like dr. Ribka Tjibtaning Ploretariat in a hearing together with the Ministry of Health Gunadi Sadikin, head of the supervisory board of drugs, foods and drink, and the director of BIOFARMA, was very harsh in criticizing various policies of the government on vaccination, even she used the sinical statement: the nation is not allowed to do a business with its people".

This new phenomenon is symmetrical with the result of the survey done by Kompas daily newspaper in the event of commemorating Youth Oath Day in 2002. The survey indicates that often social ties that are formed in the society at this time are weak. According to a lot of the respondents the same is also true with the sense of unity and the social commitment to maintain the territorial integrity (Kompas, October 28, 2002).

Arbi Sanit (2004) agreed with this result of the survey. He stated that the construction of Indonesia's nationalism is fragile. According to him, Indonesia's spirit of nationalism which has been felt since 1908 by the Indonesians has not become a strong morality and is still fragile. Furthermore, he stated that during the six decades of the independence of Indonesia the nation has not had enough assets as a nation because the concept of nationalism that was built by one regime has been eradicated by another. The weakness of this spirit of nationalism, according to Arbi Sanit, makes Indonesia left behind compared with other nations, like Malaysia and 
Singapore, which have very clear characters and identities which have made them enjoy a good progress and prosperity (Sanit, Media Indonesia, December 31, 2004). To support the statement of Arbi Sanit, the economic historian Anne Booth as cited by Yudana (2017) also stated that Indonesia is a land with many lost opportunities. The result of Kompas survey which Arbi Sanit supported is also proven by looking at various phenomena and social realities that occurred recently. The nationhood in the manifestation of a feeling of having a common fate and suffering a common hardship that has been formed as the result of being ruled by other nations which then made a cohesive bonding among the youths in the event of Youth Oath and which continually crystallized on the event of the Proclamation of Independence, which in the present study is called Jiwa dan Nilai-nilai ' 45 (The 1945 Spirit and Values), is now appearing to be dwindling. Pancasila ideology that is expected to be collective consciousness for the people and the nation of Indonesia which binds and attaches the Indonesians cohesively has lost its vitality since the inception of the reform. The ups and downs of the subject or course which is called Pancasila in our educational curriculum becomes the obvious evidence of how fragile is our understanding of the concept and procedure on how to strengthen the building of the nation character. The dream to develop our national state that is just and prosperous based on Pancasila and the 1945 Constitution has lost its meaning. The effect of globalization and the presence of various international interests in relation to the position and existence of Indonesia's nation, especially in politics and economy have increasingly worsened the condition of the nation so that Indonesia is experiencing cultural distortions and fragility of nationhood.

\section{Study Area And Data}

This study aims to study the phenomenon of the decline of social solidarity as a cultural manifestation that should be used by the Indonesian people as a living ethos to make this nation with a plural background able to exist in the midst of a very massive world current. If we listen to the journey of our nationalism as a nation, we often witness first-hand how this nation is easily divided by very instrumental and momentary matters, not substantive-fundamental matters. When UNESCO in its cultural declaration emphasized the importance of affirming local identity and at the same time accommodation of global culture in today's technological era, what Anne Booth sparked, "Indonesia is a land with many lost opportunities" seems to be confirmed when we examine our journey to Indonesia that the nation this has not had a wellestablished preparation for surfing in the global era.

Nationalism which by Kohn (1955) is said to originate in Western Europe and then touched Asia and Africa has the meaning: "the highest level of loyalty of the individual has to be submitted to the national state". In this quotation from HansKohn it is stated that the birth of nationalism in Western Europe was caused and triggered by the internal factor, that is the fight of the citizens against their rulers to demand their rights and freedom. Departing from this phenomenon, John Milton in Anhar Gonggog (1995) defines nationalism as the recognition of individual freedom from the ruler; self and personal statement stated to the government and church; the liberation of oneself from the oppression from slavery and superstitions.

Different from the phenomenon that occurred in Western Europe, in Asian and Africa, nationalism was born, encouraged and triggered by external factors, namely the reactive expression of the spirit of nationalism because of their negative interactions with Colonial imperialistic peoples from Western Europe. In other words, the nationalism of Asian and African nations was born because of "their nationality belief" that they are at the same level as the peoples who colonialized them.

As the people who has experienced the negative interactions with the Western European colonialist and imperialistic nations and Japan, of course, our existence as "the people 
of Indonesia" has been fought through a long struggle. Generally based on the character in the style of its movements, the intended struggle can be grouped into two stages, that is, the protonationalism period and the nationalism period.

The proto-nationalism period is the struggle that was fought in the form of local struggle that was led and pioneered by kings, princes and charismatic leaders of the localities. If it is seen from the great number of the struggles and movements in this period, as the generation of the nation we should be proud, since almost in all areas in our nation there had occurred preserving struggles to drive out the colonialists. The spirit of Padri people in Aceh, that of Hasanudin in Makassar, that of Diponegoro in Java up to that of Patimura in Ambon, Eastern Indonesia were the evidence about how great were the struggles by the people of this nation in the proto-nationalism era.

After the long and fruitless proto-nationalism period stage, then since 1908 starting from the founding of Budi Oetomo a new stage began in the period of struggling history of the people of Indonesia that we know as "the National Movement". By Anhar Gonggog (1995) this period of struggle iss called the brain struggle. This period was marked by the birth of organizations founded with "the Modern System". Modern here means that the organizations are completed with the organizational structures, action plans and formulations of clear goals. Another characteristic of this modern organization is the equality of the members of the organization based on "a rational sincerity "without any coercion.

Boedi Oetomo as the pioneer in this period that was built by educated youths using morality as the foundation of the organization with the goal: "To advance education of the children of the nation". As the people who were being colonialized the initiative of Boedi Oetomo that touched the moral problem and education was very important. To change poverty and stupidity by a struggle that use weapons is illogical. The human society has to be given a tool to change their fate, and the best tool for it is education.

The best idea from the educated youths who were associated in this Boedi Oetomo had become the pillar of the struggle of the next generations. Although politically it never touch the main power, as a pioneer Boedi Oetomo had been able to encourage the growth of awareness of the people of this nation to redefine nationalism as the feature of a more effective struggle on the one hand, and successful in making a significant effect on the weakening of the stability of the colonial imperialistic Netherlands in its colonies.

As the evidence that the awareness had aroused in the next period various organizations of movement were born such as Islamic Trade Association in Lawean Solo. And with various dynamics both as caused by both the internal and the external factors that were originally functioning as economic capacity building changed into a political organization called "Islamic Association".

The effect caused by the birth of Islamic Association did not only hit the stability of the colonialist-imperialist but also inspired the generation of the nation to be aware and proactive in stabilizing the root of the nationalism. This awareness was reflected in the birth of various political parties in the next periods in the form of political parties with various ideologies. The elan vitality of this event of national awakening, followed by the most dramatic episode that was made firmed by the youths of the nation in the form of Youth Oath in 1928, which had especially directed toward the objective of the elan-vitality of the revolution which was formulated together, that is, the consensus to have one nation and one people, that is, Indonesia, with Indonesian language as the language that unites the people.

The most important part of the long process of the birth of this nationalism is that on the one hand, nationalism had given birth to a new power as a way to challenge the stability of the colonialistic imperialistic Netherlands, and on the other hand, among the scholars of the 
nation had occurred discussions that were interesting about what would be the foundation of our life as the people of the nation.

The thing that deals with the foundation of the life as a people of a nation, according to Anhar Gonggong (1995) can be grouped into two important events related to the debate and polemic about the foundation of the life as a people of a nation, namely (1) the polemic between Cipto Mangunkusumo and Soetatmo Soeryokoesoemo; and (2) the debate between Soekarno and H. Agus Salim and Mohammad Natsir. The polemic between Tjipto Mangunkusumo and $\mathrm{n}$ Soetatmo started in their formulation of the type of nationalism that would be developed, that is, between Indian nationalism that was conceptualized by Cipto Mangunkusumo anda Javanese nationalism that was developed by Soetatmo. Whereas the polemic between Soekarno and H. Agus Salim started from the idea of systemization of the nation by separating religious element and the nation. By quoting the idea of Kemal Pasha in Turki, Soekarno in the magazine "Panji Islam" clearly offered the idea of separating religious affairs and the state in organizing the society. While Mohammad Natsir in his article "Dualism" in Caisaro Papisme and Kemalisten in Indonesia, offered the idea that contradicted Soekarno's.

The discussion on the consolidation and formulation of the foundation to organize the nation-state that was being attempted more intensively occurred during the Japanese occupation, especiallly in the months before the end of World War II. Through an organization with 62 members which was latter known as BPUPKI (Badan Penyelidik Usaha Persiapan Kemerdekaan Indonesia/ Investigating body on the effort to prepare Indonesia's independence), our leaders discussed the constitutional elements that would become the bases and the regulation of life in an independent nation-state.

The formulation that had been resulted in the BPUPKI period, in the period after the proclamation of independence, that is, on August 18, 1945, was accepted by PPKI the 1945 Constitution as the foundation of the national constitution of the Independent Indonesia, which in civics is called the Basic Law of the State.

Success in the erecting the pillar of Indonesian nationalism was supported by the highest degree of national loyalty so that it forms what is called by Ben Anderson as the imagined communities on the breast of every actor of a revolution (Fattah, 1999). The national loyalty is posited on the highest place, higher than the primordial and subnational loyalty so that it forms an elan-nationalism that has the spirit of egalitarianism moral consensus, spirit of togetherness and partnership as well as the autonomy of participation (Yudana, 2004). The reflective description of the tracing of the ups and downs that is full of dynamics of strengthening nationalism based on the spirit and values of Pancasila in the second part above has to become the reference in living as a people of a nation in the future if we agree to be free from Naisbit's global paradox.

\section{Methods}

The study in this paper uses a descriptive qualitative critical method, which begins with a narrative outline of the challenges that will occur, especially in the pandemic and postpandemic era, then presents a narrative of national issues that we have, and is supported by data in the form of the peaks of our Indonesian journey, to various comprehensive solutions that are presented as a strategic offer.

\section{Discussion}

Globalization, although the term has become worn out as it has been used by everybody whether they understand the meaning of the term or not, is a consequence that on the one hand it appears to transmit useful thigs but on the other hand it does not preclude the effort to cast 
deceptions which politically can trigger liberalization and culturally encourage the birth of material asceticism. However, how cliche the term globalization is, it has produced political economic, and cultural trans-nationalization. Globalization by Drucker, (1994); Soros, (1998); and Zen, (2000) is stated to give birth to an era of "Countries without borders", so that there is a free flow of human beings, goods, services, capitals, information and ideas.

In this context, as a people of a nation we are facing a very problematic choice. As a people of a nation we are in a dilemma between the drive to sustain identity (self-sustaining) and the drive to change (self-generating). The pull between the two poles give birth to paradoxes, as to become global on the one hand and to maintain the local identity on the other hand. This increasingly widespread paradox has inspired UNESCO in declaring culture by stressing how important it is to affirm local identities and at the same time to accommodate the global culture. In line with this and if we want to be honest, as a people of a nation actually we do not have a reason to admit that we have prepared this nation to enter the globalization. Without any intention to underestimate, the strengthening of nationality that was once developed in the New Order for 32 years turns out to show to larger extent ideological repression model and political mobilization (Yudana, 2004). Based on this fact it is very rational for us to say that this nation has not had enough preparation to anticipate and prepare its generation to be the contestants in the international competitions.

Once again in the context of globalization with all of the tendencies that accompany it, then the development of the national character or the 1945 spirit and values through revitalization, actualization, and education is imperative since without a stable character that is marked by the pride of becoming the citizen of the nation and has a strong love for the country one is listening to the bell of death of this country.

It is proper to to pay attention to and of course this has been triggered by today's development that in the revision of the education act in April, 2006 Japan incorporated "the love for the people of the nation and the nation" (aikokushin) as one of the targets/ objectives of their education (http://www.yomiuri.co.jp/kyoiku/ special/s03/ 20060426tv03.htm). What is interesting from this example is that if Japan which is culturally very homogeneous since it has the same ethnicity, framed by a homogeneous subjective-emotional-substantial factor and supported by the stable objective-rational -instrumental factor, formats their progress by the focus on the love of the nation, then it is very unreasonable and ahistorical if the nations with multicultural diversity like Indonesia is less sensitive toward this last issue.

There are some reasons that are vary basic why the consolidation of character of the nation in the manifestation of the love for the people and the nation becomes imperative. First, it flow downward from the fact that whether we like it or not, slowly or quickly our people will experience a social transformation toward a system of technology/technocracy as the consequence of the influx of transfer of technology from the developed nations. Closely related to the effect of technology on human beings individually, socially and the environment, the development of science and technology does not always produce good things (tonic potentialities), but it often transmits bad things (toxic potentialities). In addition, in the technocracy era under the pressure of the ultraliberal or neoliberal expansive pressure today and in the future when human rationality has been and will be increasingly hegemonic and dominated by "technical rationality " ( borrowing the post-modernist expression ), the development of technology will often has more tendencies to produce problems than usefulness for human life, the society and environment( read, among other things Ellul, 1980; and Dickson, 1979). "Technology is clearly not synonymous with the good. It can also lead to evil" (Mesthene, 1983:111) is the correct reference to anticipate the negative impacts that can be caused by the technology outflow. 
Secondly, that the concrete fact of this nation, now is in the euphoria of freedom that tends to be too extreme. Loebby Loeqman in Kompas September 14,2000 is of the opinion that beside the disease of governmentless, this nation is also suffering from nationless chronical disease. The loss of nationalism, which Megawati (2000) calls nationalism erosion, has caused an epidemic in the form of the language that is dominated by anti-humanity. Anarchism appears to be the communication standard in the system of nationalism and civics. Almost all of the pillars of life, political, social, religious, and cultural are attacked by the problem that is around the perception of "we" and "they". As the result, various relations that are made praxis tend to be based on the calculation of power of one side over the other side. "They" are not part of "us" and vise versa. It is this distinctive understanding that becomes the root of the problem of Indonesians today, so that it is not a surprise that various terms such as "unrest", "murder", and "mugging" become familiar at the bottom of the people's awareness. Today the situation of the Indonesian society (borrowing Sigmund Freud's term) is regressing to primitive psychic activity, the coming back of a group of ancient people in ourselves.

Two essential problems in our nationalism as described above, now in the middle of the surge of the covid- 19 pandemic that is devastating almost all pillars of life, increasingly reconfirm the scary repercussion that will possibly occur. For this reason, by keeping in mind the current pandemic, how important it is to reflect on the past development of our Indonesian nationalism and in the middle of the pandemic we also learn from the naturalness of the planet where we live. Learning from the way how nature develops a balance and maintains itself, as an analogy if certain animals are preying on other animals the logical explanation is it is just for survival or protecting themselves from the threat or because they are hungry. Learning from nature, we are the species that do not support other lives, thus nature will make us extinct. With this logic, the chain of life be balanced.

Actually, for the Balinese who are Hindus, who are able to understand the essence of the life philosophy of Tri Hita Karana, developing a harmony which is balanced both vertically and horizontally can be practiced as a new tradition in the new normal era today. This wise culture actually can be made a habit. Why? Since for our brothers and sisters in Bali by implementing Tri Hita Karana, let us forget about the activity of praising God which is commonly practiced with the ritual of offering which is holy, honest and sincere ; interacting among themselves, which is guided by the guidance of paras-poros selunglung sebayantaka which means "sharing each other"; even interacting with low creatures Balinese are doing it by giving an offering, known as nyomya buta which means building a harmony with nature.

In a more universal context, the author wants to offer a solution on how to live in the pandemic time and in "the post-pandemic" time. The words post pandemic is given in a quotation, since the author is influenced by the hypothesis given by the Minister of Health, Budi Gunadi Sadikin. He warned us that this Corona is not yet sure to flat down completely in 10 years to come. Thus, since he encouraged us to learn to live together with Corona virus. According to that hypothesis and suggestion, we seem to have to start to understand the nature sign to find a correct solution to develop the social resilience in the post-pandemic time, by developing a harmonic relation both vertically and horizontally for strong Indonesia.

\section{Conclusion}

Some national problems of concern above, that characterizes the damage of solidarities, which according to Naisbitt (1994) is called the death of political communities and the loss of the social roots have tp be found their solutions. However, the concrete solutions to this problem is not only is not easy to identify, but demands many prerequisites with subjectiveemotional-substantial dimension and objective-rational-instrumental dimension. 
With no intention of forgetting the contribution of subjective-emotional-substantial factors, it turns out that the problem of nationalism above is triggered more by objective- rational instrumental factors (Dahrendorf, 1996; Nasikun, 2005; and Bappenas, 2006). Based on this, a number of needs that are very necessary to be actualized in overcoming the problem of nationalism that surfaced recently are as follows.

First, the rebuilding of the damaged solidarity by overcoming -reducing-eliminating what is called by Sri Edi Swasono (2004) the default of development. The surge of the ethnic solidarity and various assertive forms of primordialism recently was not triggered by ethnic reasons. The more concrete reason from this divergence is the injustice and socio-economic gap that occur in the development process. In the pandemic era, this hypothesis is proven. Why? Since the national development that should have benefited, all parties have diverged to become divergent socio-economic and socio-cultural processes. The national development that should have been a process of group capacity building of the underclass often changed into a process of marginalizing the weak, the poor and the underprivileged. The development which should become a process of empowerment of the people has diverged into a process of impoverishment. The format of the development of prosperity which we have developed should be designed and implemented as institutional programs, rather than as residual programs.

Secondly, to maintain the future of Indonesia means to be aware of the diversities, geodiversity, bio-diversity, social-diversity, cultural-diversity and ethnic-diversity. It cannot be denied that the construction of Indonesia is erected on the primordial polarization foundation which is rich and diverse. The pluralism of Indonesia is illustrated in the possession of not less than 479 ethnics and 19 customary law regions on that diverse setting, as a nation we have committed to becoming one in a political manifest since Indonesian Association to Youth Oath in 1928. From this political manifest has been born the cultural manifest "Unity in Diversity", which parallels to The United State of America's E Pluribus. From the understanding of this plurality, it looks that the basic thing that has to be attempted is how to maintain that the primordialism from being crystallized and solidified becoming a social explosion in the form of centrifugalism movement. To maintain Indonesia by killing primordialism is impossible and an ahistorical act. The only choice is to tolerate the existence of primordialism while wisely and understandably primordial conflicts. The final goal is to maintain differences, contradictions and primordial conflicts in order that they cannot develop into separatism. For this problem, Fattah (1999) reminded the political elites not to prefer to use primordial values and interests, whose euphoria is often seen in the time of election. It is important to stop this preference since it is here "the ember" of separatism can go into "a scary big fire." the importance of the development of a dialogic democracy that does not only function as a method to arrange interests, but also as a way to create a public arena where controversial issues can be solved.

Thirdly, Giddens as cited in Nasikun (2005) stresses the importance of the development of generative politics that gives the state a role as a cybernetic intelligence and on the other hand it gives opportunities to the people to solve the problems that they face by themselves. The error in the long history of this nation is the negation of interactions among the plural elements that make it possible for the development of a public space for developing a plural society. These interactions have to be promoted as something that is necessary. The paradigm of the nation's elites (which was very easy to see in the New Order era) that saw such opportunities more as having more chances to result in social disintegration than social stability has to be ended. We have to be aware that to build social stabilities by eradicating pluralities will cause a problem. The partial characteristic was seen in the appearance of a discourse that was presented with the term reformation that saw changes only from the state's point of view rather than from the point of view of the society (civil society). Actually, according to Fattah 
(1999) in the context of change, the need to manage civil society proportionally with the "control formula": giving proportional autonomy and control wisely is very basic. Ralf Dahrendorf (1996) showed that one of the factors that triggered revolutions in Europe was the failure to manage civil society that was still developing into a substantial power outside the state and that was strengthening itself vis a vis the state. If we learn from Dahrendorf it means that we manage our civil society so that it does not create a strong collision with the state and ruin the building of Indonesia, which is now in the pandemic and after the pandemic become the conditio sinqua-non.

Fourth, the models of ideological repression and political mobilization should be eradicated. The experience of dividing the nation-states in Balkan Peninsula such as Soviet Union, Yugoslavia and Chekoslovakia teaches us that the building of Indonesia will become fragile if it is filled with humans who are being controlled and oppressed under an ideological repression and political mobilization (Fattah, 1999). The practice of forcing the implementation of the principles of communitarian; mobilization toward the appreciation of authority and power and the practices of leading people toward pseudo-consensuses are clearly unsuitable for the effort to design "Future Indonesia". It is far wiser to fence the nation-state strongly by appreciating the existing differences. The unity in diversity has to be adopted as the explicitness and at the same time is understood as something which is das Sein, while we uphold as an abstraction of culture and at the same time as das Sollen.

Fifth, the future of Indonesia can only be maintained if we are able to avoid leadership crisis. In line with this, now and toward the future a new paradigm is appearing about the economic system and global politics. The new paradigm is popularly known as Good Governance, which substantively has become the ideology of international donor institutions (World Bank, UNDP, European Bank for Reconstruction and Development, and Asian Development Bank) in encouraging the member states to appreciate the market principle of economy and democracy as the prerequisite to become players in the international socialization of the 21 st century. In addition, the paradigm is also one of the conditions for newly developing nations to get aids or loans, or to get help or loans from the international financial institutions.

Fifthly this is the crucial agenda in safeguarding strong Indonesia and in refusing Naisbitt's scenario as expressed in his book Global Paradox (1994) which became the best seller, that mentions the era of the beginning of history that can multiply the assertiveness of primordialism and trigger the national disintegration. All of these are very essential for development, which by Denis Goulet (in Nasikun, 2005) is called moral austerity that is needed for the development of spirit and authentic social solidarity to develop a social resilience in facing social shocks as the access of the covid -19 pandemic. In the political sector, the elites need to become the role models in democratic civility development in order not to repeat the split of the nation like a wise man will not make the same mistake twice.

\section{References}

[1] Anhar, Gonggong. 1995. Sejarah Perkembangan Nasionalisme. (Makalah disampaikan pada Semnas Humanika, 2-3 Agustus 1995). Jakarta

[2] Arbi, Sanit. "Konstruksi Kebangsaan Indonesia Rapuh" dalam Media Indonesia , edisi 31 Desember 2004

[3] Banks, James. 1981. Multietnic Education : Theory and Practise. Boston : Allyn and Bacon.

[4] Dahrendorf, Ralf. 1996. Economic Oportunity, Civil Society and Political Librty, dalam Development and Change, Vol. 27, No.2. 
[5] Dickson, David. 1975. The Politics of Alternative Technology. Second Printing. New York: Universe Books.

[6] Drucker, Peter. 1993. Post Capitalist Society. New York: Harper Bussines Series.

[7] Ellul, Jacquees. 1980. The Technological System. New York: The Continum Publishing Corporation.

[8] Fattah, Saefulloh. 1999. Membangun Oposisi (Agenda Perubahan Politik Masa Depan). Bandung: Remaja Rosdakarya.

[9] Giddens, Anthony. 1998. The Third Way: The Renewal of Social Democracy, Blackwell Publisher Ltd.

[10] Kohn, Hans. 1995. Nasionalisme, Its Meaning and History (Edisi terjemahan). Jakarta: Pembangunan Erlangga.

[11] Mesthene, Emmanuel. 1983. Technology and Wisdom, dalam Carl Mitchamand Robert Mackey (Eds), Philosophy and Technology: Readings in the Philosophical Problems of Technology, New York: The Free Press.

[12] Mufid, Ahmad Syafii. 2001. Dialog Agama dan Kebangsaan. Jakarta: Zikrul Hakim.

[13] Naisbitt, John. 1994. Global Paradox. Jakarta: Binarupa Aksara.

[14] Nasikun. 2005. Peran Ilmu-Ilmu Sosial dan Humaniora Bagi Librasi dan Humanisasi Teknolgi. Makalah Bahan Kuliah Perdana Program S2 dan S3 Pascasarjana UGM. Yogyakarta.

[15] Soros, George. 1998. Toward a Global Open - Society. New York: John Wely\&Son

[16] Supriadi, Dedi. 2001. Kreativitas, Kebudayaan, dan Perkembangan IPTEK. Bandung: Alfabeta.

[17] Swasono, Sri-Edi. 2004. Kebangsaan , Kerakyatan, dan Jatidiri Bangsa. Surabaya: Konaspi V

[18] Stavenhagen. 1986. Problems and Prospects of Multiethnic States. Tokyo : United Nation Uni. Press.

[19] Wells George. 1951. The Outline of History. London: Casel and Company.

[20] Yudana, Made. 2004. Revitalisasi Nilai-Nilai Pancasila Untuk Mengokohkan Nasionalisme Kebangsaan Menuju Masyarakat Madani Indoneia ( Makalah dalam Sarasehan Peringatan Kesaktian Pancasila Tanggal 1 Oktober 2004 di Auditorium Universitas Udayana Kampus Jimbaran Denpasar.

[21] Yudana, Made. 2017. Menggugah Perilaku Teladan Politisi, Dalam Rangka Mempersiapkan Generasi Muda Berdemokrasi Secara Elegan. (Makalah dalam Seminar Politik PORKOMKOM Buleleng di Hotel Banyualit Lovina Singaraja. Jumat 23 Oktober 2017).

[22] Zen, M.T. 2000. Masyarakat Terbuka. (Makalah disampaikan pada Semnas. Wilayah Timur Perguruan Tinggi di Surabaya, Tanggal 29 Januari 2000) Surabaya. 